\title{
The Politics of Space: Vietnam as a Communist Heterotopia in Viet Thanh Nguyen's The Refugees
}

\author{
MOUSSA POURYA ASL \\ School of Humanities \\ Universiti Sains Malaysia \\ moussa.pourya@usm.my
}

\begin{abstract}
Viet Thanh Nguyen's The Refugees (2017) explores hardships and aspirations of non-Communist Vietnamese led between two contradicting geographical imaginations. This article draws upon Foucault's theories of "other spaces"-heterotopia, utopia and dystopia-to examine the socio-political constructs of space in the manufacturing and diffusion of desired knowledge(s) throughout the collection. It is argued that the particular arrangement of spaces together with the strategic monopolization of knowledge-producing practices throughout the stories produce the effects of regulatory and disciplinary power with the aim of naturalizing certain discursiveideological policies. The analyses of selected stories unravel the ways in which the Communist Vietnam is ideologically signed as a heterotopia, or a rupture of a decent society. The study also reveals that such negative depictions of the country are in compliance with mainstream epistemic perspectives in the West that aim to maintain a similar discursive regime. Hence, it is concluded that the juxtaposition of two irreconcilable spacesthe heterotopic representation of Vietnam in relation to the utopianised picture of America-feeds into the contemporary discourse of war on terror by reflecting the Cold War register of anxiety about an insidious Communist threat.
\end{abstract}

Keywords: heterotopic spaces; Michel Foucault; communism; Vietnamese American literature; The Refugees

\section{INTRODUCTION}

The epoch following the 9/11 events in America has witnessed the re-emergence of a new variant of the demonizing discourse of American nationalism which was mainly in practice during the Cold War, when Communism was taken as "a murderous ideology detrimental to human freedom" (Radzilowski, 2009, p. 1). The growing cultural anxiety in the past two decades has led to the reconstruction of high-risk categories such as "terrorist" and threatening "refugees" as gravely menacing to the security of the American nation and nation-state, allowing the exercise of new regulatory and disciplinary mechanisms to monitor and control certain kinds of bodies and spaces to suppress potential threats (Sheth, 2011, p. 58). On the one hand, a systematic rise of a new security-oriented political discourse has helped to mobilize certain discursive-ideological policies such as legitimization and valorisation of America's past and present militaristic interventions around the globe. On the other hand, it has criminalized individual and collective associations with any ideologies - not least Islamic fundamentalism and Communism - that pose a potential threat to mainstream American liberal way of life (Asl, 2019). It is this dominance of Americanization of world order that can be related to the current study on Vietnamese diasporic literature. That is, at the level of anti-Communism, the American demonology has been systematically glorified in recent years through the medium of popular culture, in particular to Vietnamese diasporic literature, which reflects the Cold War register of anxiety about a Communist threat.

Within the contemporary context of reinvigorated American nationalism, Vietnamese Americans' recollections of their country of birth before, during, and after the American war in Vietnam-or the Cold War-era proxy war against Communist threat-have gained increasing public and scholarly attention. Due to their direct or indirect connection to the war 
and because they come from a Communist society, Vietnamese Americans have frequently been "perceived not as refugeed allies but as invasive enemies" (Janette, 2018, p. 9), and have thus faced strong "pressure of representation" (Pelaud, 2011, p. 2). The rampant racialization practiced throughout the majority culture has shaped the content of literary writings by or about the refugees. Post-war Vietnamese American writers have sought to disrupt the dominant misperceptions and reassert their pro-Western position and political allegiances by critiquing Communist ideology through stories of loss, trauma, tragedy, malevolence, and pain caused by the rise of Communism in their country of birth. Infused with anti-Communist view of the homeland, however, the refugees' debatable representations have helped to reinforce the demonized image of Vietnam as a Communist evil aggressor, and hence "a surreal backdrop to a US psychic wound" (Janette, 2018, p. 1), by locating the causes of their own exilic suffering in a place where barbarism, violence and inhuman practices are sanctioned.

The Pulitzer Prize-winning author of The Sympathizer (2015), Viet Thanh Nguyen is at the forefront of Vietnamese refugee writers. Published in the course of the growing nationalist discourse in America and right after the fortieth anniversary of the Communists' Resistance War against America in the Socialist Republic of Vietnam, Nguyen's stories of Vietnam, Vietnamese people, and Vietnamese Americans in his debut novel The Sympathizer (2015) and short story collection The Refugees (2017) have attracted increased attention. As a post-war refugee, his personal experiences with conflicting ideologies are reflected in both works which provide critique of the war-time North Vietnamese and post-war Vietnamese Communist regimes through memories and histories of the war. Drawing upon Michel Foucault's contention about the present era as the "epoch of space" and "juxtaposition," this article analyses Nguyen's The Refugees (2017) to examine how the stories' juxtaposition of two irreconcilable spaces, namely the Communist Vietnam and the free world of America, feeds into the long-standing discourse of conservative anti-Communism prevalent in the United States.

As a theoretical approach, Foucault's theories of "other spaces"- -heterotopia, utopia and dystopia - are used to examine the various ways in which Communism and anti-imperialist nationalism shape the heterotopian realities of Communist Vietnam in Nguyen's stories. It is argued that Vietnam, a former battleground in the global struggle against Communist aggression, is portrayed as a heterotopia in relation to the free world (i.e., America), where heterotopia in this anti-Communist context refers to "a space where the normal and accepted logic and rules of a society are suspended, such that things that can be done in the heterotopia which are not allowed or accepted in 'decent society"' (Villet, 2018, p. 13). Communist Vietnam, depicted as an outpost and heterotopia of the democratic world, is a place where organized oppression, mass incarceration, systematic dehumanization and political genocide are sanctioned. This idea of a Communist heterotopia rests on the fundamental assumption that heterotopias are sites of Otherness, divergent from accepted norms, and "in excessive of or incongruous to the normative standards of a sociocultural or historical location" [emphasis original] (Hook \& Vrdoljak, 2002, p. 210). Notwithstanding its geographical and territorial difference, the portrayed Communist society in Nguyen's stories remains a heterotopia as it is described by its otherness in relation to a socially-politically liberal locality.

The Refugees offers itself for such an investigation of spatial mechanisms because as the title suggests, the stories are about individuals who have fled from brutal dehumanization in their native country for safety to a liberating geographical location. The collection is comprised of eight stories that depict hardships and aspirations of individuals led between two contradicting geographical imaginations: their country of birth as a site of social exclusion and their adopted homeland as a utopian space of opportunities. By dystopianising the past and the homeland and describing the monstrous crimes the state perpetrates against its own people, Nguyen portrays Communist Vietnam as a rupture of a decent society, or the civilized liberal 
American order of things. Throughout the stories, the prevailing Communist ideology and antiimperialist nationalism in Vietnam are experienced, from a Vietnamese American viewpoint, as an imminent rupture to the normative democratic American order of things.

Foucault's spatio-temporal notion of heterotopia is related to Nguyen's approach in the sense that it problematizes the representation of an "other" society in remaking of distant memories of Communist violence and the lingering dynamics of a repressive political consciousness. It provides some of the many means to read the narratives in relation to a utopian/dystopian axis, and interpret them within a heterotopian, either hypertopian or hypotopian, context (Amarinthnukrowh, 2019; Asl, Abdullah, \& Yaapar, 2020; Dwyarie \& Tjahjani 2019). In other words, this approach allows us to explore the functionings of the existing narrative discourses as they are elaborated at particular temporal and spatial locations. Furthermore, by situating Nguyen's fictional representations of heterotopic Communism within the contemporary context of the "war on terror," this essay expands upon recent scholarship that speaks of manifold "strategic memory projects" and "place-making" in America to diffuse anti-Communist "exile identity" and to frame collective discourse on the War by restoring the heroic ideology of American exceptionalism (Aguilar-San Juan, 2009; Eyerman, Madigan, \& Ring, 2017; Y. T. Nguyen, 2018). In doing so, the study renders an understanding of the socio-political present that constantly aims at exercising new forms of power by subjugating knowledge and constructing framed memories.

\section{THE WAR ON TERROR AND THE VIETNAMESE AMERICANS}

The 9/11 terrorist attacks in 2001 provides powerful reinforcement of a complex reality of a long-existing sovereign authority in America. Aimed to strengthen national security, the Congress passed the USA PATRIOT Act that serves" $[\mathrm{t}] \mathrm{o}$ deter and punish terrorist acts in the United States" (Public Law, pp. 107-56). The bill inscribed new forms of American nationalism and racial divisions through various disciplinary and regulatory technologies of power such as the "War on Terror" campaign. In addition to the subsequent growing antipathy towards Muslims and Arabs, the traditional Cold War demonology in American politics was resurged, leading to a new epoch of fear and security-oriented policies and practices. At political level, Communism has been reconstituted as an evil force that equally poses an insidious threat to American national identity. The imminent danger of an ideological attack by Communism further provoked a disciplinary framework to detect, control and regulate risk-producing individuals and communities in order to pre-empt and minimize disruptions to the dominant political regime. As a regulatory strategy, biopower was necessarily exercised to incarcerate and criminalize certain kinds of bodies which could be construed as ideologically dangerous to the American way of life (Asl \& Abdullah, 2017; Grewal, 2003). Foucault explains biopower as,

\footnotetext{
[a] technology which brings together the mass effects characteristic of a population, which tries to control the series of random events that can occur in a living mass, a technology which tries to predict the probability of those events ... This is a technology which aims to establish a sort of homeostasis, not by training individuals, but by achieving an overall equilibrium that protects the security of the whole from internal dangers.

(Foucault, 2003, p. 249)
}

The post-9/11 governmental rationality of America used biopower as the power of "normalization" to divide individuals along the lines of good and bad races. As Grewal (2003) observes, the image of the Oriental other, in particular "[t]he Muslim as terrorist and the racialised figure of the person who 'looks like a Muslim' as a racial figure of the 'terrorist'" together with the Communist as anti-democratic, was reconstructed in the process of controlling, regulating and annihilating "those who are believed to provide the highest risk to the nation" (p. 540). This was accompanied by disciplinary mechanisms that sought to circulate 
state-established norms through cultural productions (Grewal, 2005). While biopower has criminalized Communists and Muslims as the evil ones because of their alleged aversion to the prevailing democracy of the States, the disciplinary power has sought to systematically reconstruct, reimagine and retell the popular and official narratives about American wars against Communism in its own political interests. Effective agents in the diffusion of the framed narratives are the exiled first- and second-generation American-based and educated immigrants who explore the past into an American future in a desperate struggle for assimilation and integration into the mainstream culture.

It is possible to see how at an ideological level Vietnamese refugees could be racially criminalized as a potential threat to security of the American nation, and politically exploited as agents to fulfil certain objectives by reshaping recent history. The incarceration and criminalization of these people began in 1960s and 70s as part of the American demonology that rigidly insisted on the menace of the Oriental Other. In the tumult of the Cold War and on account of the prevailing conscious Communist propaganda, the first generation refugees were completely unwelcomed in America (Klein, 2003). Upon their arrival, they were located in refugee camps in military bases (Eyerman et al., 2017, p. 25), and fell victim to "racial discrimination and involuntary segregation" (Schlund-Vials, Võ, \& Wong, 2015, p. 31). The only way to be accepted by U.S. immigration and be safe from rampant racism was for the refugees to "prove that they were political refugees" who held anti-Communist beliefs and rejected antidemocratic, anticapitalistic principles ( $\mathrm{Vu}, 2015$, p. 208). Hence, in constant struggle for acceptance and recognition, the Vietnamese refugees have always sought to redefine their identities based on American nationalism by publicly expressing their antiCommunist stance, valorising "bourgeois capitalism" and expressing solidarity with the ongoing war against terrorism and totalitarian societies (Booker, 1994, p. 20; Pinak \& Lalbakhsh, 2019). Through continuous self-regulation, Vietnamese Americans have set themselves as an anti-Communist model minority, mobilizing the overarching "good refugee" narrative in America.

Regulating Vietnamese individuals to produce "good refugees" has allowed a disciplinary reconstruction and redefinition of space and knowledge in the process of legitimizing dominant discursive-ideological policies. On the one hand, good refugees' antiCommunist trope reduces the "multifaceted histories" of the War in Vietnam to a one-sided story about Communist oppression. This reductive version of history, as Le Espiritu (2006) aptly points out, "mobilizes beliefs in the fundamental decency of Americans and in their ability to promote democracy and freedom worldwide" (p. 338). Hence the significance of fabricating new knowledge by remaking war memories alongside U.S. nationalist rhetoric in naturalizing and reinforcing certain political discourses. On the other hand, the good refugee narrative helps to authenticate America as the locus of democracy and freedom, and in so doing discursively distances the liberal world "from 'communism' and more recently from "terrorism" (Le Espiritu, 2006, p. 346). Within this overarching narrative, Vietnam is negatively depicted as a place of unfreedom, violence and horror-hence, an object of U.S. rescue fantasies. The dystopian impulse in Vietnamese American narratives re-produces the twentieth century dystopian trope of political dichotomy "between totalitarianism and democracy, where 'democracy' implies the individual liberty (real or illusory) presumed in conventional bourgeois societies" exemplified by the United States (Booker, 1994, p. 20). Strategically, this social and political, but ahistorical, juxtaposition of the two spaces reinforces the wide disparity of life conditions and normalizes anti-Communist, U.S. nationalist rhetoric.

The predominance of anti-Communist rhetoric as the epistemic perspective in producing stories about Vietnam has sparked off debate on the issue of representation, leading to a great depreciation of the post-war Vietnamese refugee stories for being systematically manipulated by a politically-orchestrated collective memory. It is widely acknowledged that 
the Vietnamese American literature is mainly produced in compliance with official state apparatus in a conscious attempt to filter recollected past through present needs $(\mathrm{Vu}, 2015)$. The legacies of the war are controlled to glorify and commemorate certain individuals and groups while eliminating others-e.g., the Communist Vietnamese who "cannot be designated as 'ours' [i.e., American]" (Sylvester, 2017, p. 9) - from mainstream historical narratives. The literature is criticised for reconstructing and appropriating some memories as dominant while displacing others as unworthy of remembering (Appy, 2015; Eyerman et al., 2017; Nguyen, 2016; Sylvester, 2017). With respect to the ongoing battle among power/knowledge frameworks, it is timely to examine the various ways in which space and knowledge are appropriated in Nguyen's stories. However, unless one appreciates the significance of Foucault's theories of "other spaces," one cannot appreciate the politics of spaces in the stories, nor can one fully comprehend how the collection serves as a conscious anti-Communist propaganda tool within the contemporary discourse of the "War on Terror." Hence in what follows, the essay offers a critique of Foucauldian (other) spaces, and then analyses Nguyen's stories to explore the social-political formations of space and knowledge.

\section{A HETEROTOPIC SPACE: FOUCAULT'S DEFINITION}

Space and spatial relations are significant in understanding human relations, politics and identity formation (Howarth, 2006). For Foucault, "space is fundamental in any exercise of power," because the way space is constructed, experienced and utilized directly affects the ways individual identities are formulated and social relations are orchestrated (Foucault, 1999, p. 140). This means that space is not only a normalized locality but itself can serve as a normalizing force. In other words, the structure of the space is necessary, but not sufficient, in the functioning of networks of power. The way a space is created and understood not only determines "the distribution of bodies" within that particular location (Leib, 2017, p. 195), but also shapes the subsequent modalities of governmentality, or the "means of control" and methods of domination (Foucault, 1995, p. 191). If the existence of a site is experienced as terrorizing, and its occupants are defined as "ontologically distinct creatures" (Sheth, 2011, p. 59), they can be subjected to restraining technologies of power. The air of menace, or the "ideological signing" of that particular locality as dangerous, prompts a disciplinary mechanism that will monitor, regulate and annihilate the potential threat insofar as it does not contest or disturb the dominant discursive regime (Billingham, 2000, p. 5). The pre-normalized space with its decent citizens exists in contradistinction to the threatening un-normalized sphere with its ungoverned or ungovernable, occupants who are yet to be subjected to governmental rationalities.

Within this system of juxtaposition, space is conventionally defined in binary opposition: utopia and its defining antithesis dystopia. Whereas the former is a place of "harmony, consolation, and happiness," the latter is the locus of constraint, despair and fear (Silverman, 1980, p. 171). Utopia refers to an ideal community or a perfect space that is an object of aspiration. It is a spatially unattainable society where a happy life is possible. It is a blueprint "of the good (or even perfect) society" which is not real (Levitas, 2003, p. 3). Rather, it is a "no place," a promised land that exists only within the world of imagination and dream (Whittaker, 2011, p. 122). According to Foucault, utopias are "sites with no real place. They are sites that have a general relation of direct or inverted analogy with the real space of Society. They present society itself in a perfected form, ... [and] are fundamentally unreal spaces" [emphasis mine] (Foucault, 1986, p. 24). A concrete realization of this impossible unreal ideal is the normalized space of eutopia, which is a synonym for "good place." Eutopias render the attainment of a real place. They are "spaces of status, of discipline and control, and being in 
practice spaces of power, they summon exclusion: reserved for the few, rich and powerful" (Doudaki, 2018, p. 12). A pre-condition for the realization of this perfect place is perpetuation of complete harmony, both spatially and temporally. A place with no established order is thus a nightmarish negation of the ideal (both real and unreal) good place.

Dystopian spaces are therefore perceived as counter-utopias. Unlike utopias/eutopias, they are unsettling spaces filled with defective workings of social formations, and are completely paralyzed by social bleakness and constraints. Dystopian discourses are grounded on the Manichean assumption that evil is at war with virtue, with the imminent danger of the latter's catastrophic defeat. The antiutopian space may have a moral, political, economic, or intellectual root cause, ranging from sin and ignorance to absolute totalitarianism; for the Vietnamese refugees in Nguyen's fiction, for example, the root cause is the memories of Communism. Being inherently pessimistic, that is with no or little hope for positive transformation and upward movement, dystopias attain harmony only through enforced accord. Nevertheless, the existence of a dystopian space remains crucial to the actualization of the good place. Using Marxist utopian theories of Ernst Bloch, Bill Ashcroft points to the ambiguous relationship between utopias and dystopias within postcolonial literature, arguing that the dystopian world of despair, authoritarian regime, restrictions, poverty and degradation provide the initial impetus for utopias. Both the anticipated world of utopia and the real space of eutopia cannot exist without traumatic memories of a dystopian past or the disempowering reality of an antiutopian present (Ashcroft, 2009 \& 2017). Dystopia thus functions as a mirror to the good place, whereby the latter defines itself against monstrous (un-)real spaces and possible imperfections - much like the way liberal America is portrayed in juxtaposition to the frightening memories of a Communist country.

Apart from the unreal spaces of utopia/dystopia, in "Of Other Spaces," Foucault delineates heterotopia as an in-between space that exists as a discursive reality. Heterotopia is a spatio-temporal concept that represents the horizontal axis intersecting the vertical axis of utopia/dystopia binary - with utopia above and dystopia below - at the neutral degree of here and now. Heterotopic spaces are of three topological types: hypertopian, hypotopian, or neutral ones. Whereas the first refers to a real good place (i.e., eutopia) and points above the horizontal axis, hypotopia denotes a disagreeable location that leans below the axis towards dystopia. Therefore, the two spaces present opposite real worlds: a de-generate utopia, or what Silverman refers to as "a lived fiction of human life" (Silverman, 1980, p. 176), versus a chaotic landscape that demonstrate disorder and deficiency. A hypertopic space is a structural realization of the fictional features of utopia, the ideal model in which city and country spaces are enriched and fully developed. In contrast, hypotopic spaces with their deplorable nature, and undermined with operating oppressive and repressive systems, entail reformation and reordering. Yet in between the two opposite spaces there exist neutral localities-with their own ideological significance - that remain systematically overlooked. These are the ordinary discourses of everyday life whose meaning is not assigned either positively as an exemplary model or negatively as a lack.

This last point underlines the Foucauldian idea that at the interface between here-andnow good and bad places lies the locus of contesting social forces and workings of power that aim at attributing each other either as good or bad places. Representative example in Nguyen's narrative would be the two polar opposites of Communist North and anti-Communist South Vietnam. This spatiality suggests two main points: First, Communist (North) Vietnam with its distinctive spatio-temporality is defined as a space of otherness, a hypotopian site within or without civil society that works as a mirror of order or disorder to both hypertopian antiCommunist South Vietnam and its eutopian political advocate, the United States. Therefore, Vietnam is limned both as a hypotopian space that is paradoxically separate from and linked to all other localities, and as a heterotopia that consists of antagonist landscapes. In the war-time 
Vietnam, when the country is spatio-ideologically divided in polar extremes, there are disparate localities that "mirror, reflect, represent, designate, speak about all other sites but at the same time suspend, neutralize, invert, contest and contradict those sites" (Johnson, 2006, p. 78). This possibility of rupture in the desirable way of living presents the imminent danger of hypotopia eclipsing hypertopia.

Second, the clash of ideologies, and the collision and overlapping of epistemes create new ways of knowing, forgetting and remembering which is crucial for exercising governing practices. On the one hand, the simultaneous juxtaposition and combination of different spaces in one place that interrogates the coherence of the place and problematizes the existing formations of knowledge; and on the other, it leads to the appropriation or "intensification of knowledge" (Topinka, 2010, p. 56), making order and re-ordering legible (Asl, 2018a \& 2018b). According to Foucault, it is within these spatio-ideological battles that some forms of knowledge are "subjugated"- that is, some experiences or memories are systematically disqualified as "hierarchically inferior" by the hegemonic discourses (Foucault, 2003, p. 7). In what follows, the article seeks to explore these two points, namely, heterotopic spatiality of Vietnam and the subjugation of knowledge about the country.

\section{DESIRED AND UNDESIRED SPACES: VIETNAM AS A HETEROTOPIA OF THE U.S}

The Refugees presents the Communist Vietnam as the locus of torture, slaughter, deprivation, disorder, and contradicting ideologies where an organized system of criminalization, traumatization and dehumanization is sanctioned. This hypotopian space, however, is not presented in a void but in connection to "other emplacements" (Foucault, 1998, p. 178), in such a way that it represents and challenges them at the same time. Indeed, the portrayed Communist Vietnam functions as an outpost and heterotopia of American liberal life by reflecting and contesting it simultaneously. In other words, the enclosed space of Vietnam with its conflicting ideologies, or spaces within a space, embodies all the vital disruptive ingredients of heterotopia both within itself and in relation to the existing discursive order of America. The heterotopic manifestations of Nguyen's stories can best be explained in relation to the six principles of heterotopia that Foucault delineates in "Of Other Spaces."

Here, a brief review of all the six characteristics of heterotopia is helpful before illustrating the argument with examples from the stories. According to Foucault, the first principle of heterotopic spaces describes that even though heterotopias are universal, they can be found in every culture and in varied forms (Foucault, 1986). However, he classifies heterotopias in two main categories of heterotopia of crisis and heterotopia of deviance. The former refers to a space that is "reserved for individuals who are, in relation to society and the human environment in which they live, in a state of crisis," and the latter indicates a space "where individuals whose behavior is deviant in relation to the required mean or norm" (Foucault, 1986, p. 24). The second principle relates to an existing heterotopia which can function in vastly different fashions with respect to the passage of time and "according to the synchrony of the culture in which it occurs" (p. 25). The third trait of a heterotopia is its capacity to juxtapose incompatible spaces in one space. The fourth is heterotopias' connection to "slices in time," or what Foucault terms heterochronies. These are the spaces that suspend linear time as either spaces of accumulating time or spaces that are connected to "time in its most fleeting, transitory, precarious aspect" (p. 26). The fifth principle is that heterotopias require "a system of opening and closing" that both isolates them from other spaces and retains their penetrability. And the last trait is that heterotopia has "a function in relation to all the space that remains" (p. 27). It exists as radically other, or a potential threat, to the cohesiveness of an existing discursive order. 
Heterotopia of crisis as the space in which individuals live "in a state of crisis" aptly describes both the hypotopic living situation of people in Vietnam and its connection to a purportedly eutopian world far beyond its borders. In Nguyen's stories, the situation of crisis can be explained in terms of solastalgia, where (diasporic) Vietnamese individuals and communities suffer great pain and distress about the loss of an endemic sense of their country. Coined by Glenn Albrecht, solastalgia occurs when there is recognition that the present state of one's "beloved place is under assault" by human-induced changes such as war and terrorism or by natural disasters (Albrecht, 2006, p. 35). Similar accounts are given by Vietnamese citizens who have experienced the severe impact of the Communist takeover in their beloved land. In addition to the haunting memories of the refugees, the growingly dreadful life conditions in Vietnam are vividly described by native informers, who have remained within the country, through letters to their diasporic relatives in the United States. One illustrative example is the "letters thick with trouble" in the third story, the "War Years," about the gloomy life in the country that can be summed up "to the tune of no food and no money, no school and no hope" (Nguyen, 2017, p. 57). This particularly negative image of the country is stereotypically repeated throughout the collection. In the "Fatherland," Phuong and her parents, Mr. and Mrs. Ly, similarly perceive themselves as victims of the country's unfavourable sociopolitical changes, and hence "feel homesick for the past within the context of their own places of dwelling" (Villet, 2018, p. 19). For them, the world is divided into "those who stayed and those who left" for America for a better life (Nguyen, 2017, p. 200). America offers to these characters - in particular to Phuong, as she reveals it to us in a conversation with her sister Vivien - infinite options and opportunities for freedom, education, prosperity and for identity formation (Nguyen, 2017, p. 200). Yet the most poignant moment of solastalgia occurs in the fifth story, "I'd Love You To Want Me," when Mrs. Khanh and her husband, the professor, return to Saigon to visit their old house. The city, however, has so negatively transformed after its Communist takeover that they find it difficult to locate their house. As we are told, the bleak landscape with "tears of rust streaking the walls" leaves them both "overwhelmed by sadness and rage, fuming as they wondered who these strangers were who had taken such poor care of their house" and the city (pp. 117-8). The desolation and negative transformation of the country leads diasporic Vietnamese directly experience their sense of identity and belonging undermined, and at the same time, as emphasized by Liem of "The Other Man," feel content with their lives in America, especially when they compare their fate with that of their friends and relatives back home (p. 38).

The relational aspect of Communist Vietnam as heterotopia of crisis to the refugees' contemporary eutopian space in America renders the possibility of considering a Communist community in America as a heterotopia of deviance-one that deserves to be monitored, punished and regulated. In other words, the heterotopia of crisis represents, designates, and speaks about an abnormal location but at the same time contests and contradicts the hypertopian and eutopian spaces by terrorizing them with a "relational disruption in time and space" (Johnson, 2006, p. 78). In this manner, when Vietnamese refugees like Mrs. Binh or the narrator's mother of the "War Years" are averse to donate in support of a secret front in America formed to remake South Vietnamese anti-Communism, they are immediately considered as deviants for their alleged Communist sympathies, and their businesses are boycotted. Such ideological perceptions of abnormality-be it public or private-which threaten to cause severe disruption of the refugees' newly-found hypertopian space render the functioning of micro-physics of power. Therefore, as Foucault (1999) regards space to be "fundamental in any exercise of power" (p. 140), the refugees' eutopian space in America is presented as a space of privilege, of discipline and punish, of power and exclusion: a good place constructed for the normal and the civil. Without the constant gaze of a monitoring and regulating watchful eye, or panoptic mechanism, the cohesiveness of the real good place could 
be destabilized by the perils and crises of an unreal dystopian past and an existing hypotopian space.

Hence, the juxtaposition of incompatible spaces in Nguyen's stories is presented in two ways. Whereas America is portrayed as an example of a real good place where refugees find individual freedom, Vietnam is depicted first as a de-generate dystopia in relation to itself, not least to its own Southern republican part, and then after the Communist takeover, as an absolute dystopian space in relation to other good emplacements. In both cases, Vietnam functions as the other site that both reflects and contests the infinite possibilities for self-discovery offered in America-e.g., to Liem of "The Other Man" who gains sexual freedom and redefines his identity in America, or to Phuong of the "Fatherland" for whom America grants individual liberty. In other words, the incompatible spaces are juxtaposed first in terms of the heterotopian experience of the same space by anti-Communist South Vietnamese and the Communist North and, second, with respect to the contrasting experience anti-Communist refugees have in America. The Vietnam before the Fall of Saigon in 1975, when the country is still divided in polar ideological extremes, is portrayed as a de-generate dystopia that "demonstrates a lack, an absence of topological fullness" (Silverman, 1980, p. 176), suggesting that imagination, reformation and reconstruction are politically feasible. After the Communist takeover, however and according to the narrator's mother in "War Years," nation-building in South Vietnam necessarily becomes "a lost cause" (Nguyen, 2017, p. 57). After the dwelling space of antiCommunist Vietnamese in the South is invaded, seized and appropriated into crisis, the entire country turns into a dystopic space in which there is no hope for positive socio-political restorations. These contrasting experiences demonstrate how living in North Vietnam, and then the entire country, is a heterotopic experience to non-Communist (South) Vietnamese at a local level and to liberal Americans at a global level. Similarly, if the Communist Vietnamese are located in eutopian space of the United States, their encounter with that de-generate utopian space would be a heterotopian experience of incompatibility.

Even though the multiple ways space is experienced in Nguyen's stories is significant in shaping identities of the Vietnamese refugees, the characters' interaction with space cannot be dissociated from time. In explaining the fourth principle, Foucault (1986) argues that "heterotopias and heterochronies are structured and distributed in a relatively complex fashion" (p. 26). Heterotopia through heterochrony is enacted at "full capacity" when traditional time is interrupted absolutely. The Refugees is replete with examples of such temporal breaks. Perhaps that is why in the opening to the collection, Nguyen cites from Roberto Blano's Antwerp that the book is written "for ghosts, who, because they are outside of time, are the only ones with time" (Nguyen, 2017, p. viii). At the level of heterochrony as a slice of time in Vietnam, it is obvious that death, murder, the possibility of losing life, torture, rape, and violent crime are endemic. Ubiquity of these frightening occurrences creates a heterotopian experience for nonCommunist Vietnamese because the growing malfunctioning of social formations proliferates anxiety and fear. The opening story "Black-Eyed Women" contains a characteristic example of a heterochrony (a slice of time) that recurs throughout the collection, the non-Communist Vietnamese; here, the narrator-protagonist and his mother, experience the possibility of death during their fleeing from Vietnam but somehow manage to escape it. The persistence of violence and disorder in war-time Vietnam paralyzes almost all the characters with feelings of fear and angst, which is in part why it is called "a haunted country" (Nguyen, 2017, p. 5). In America, however, the most significant example of heterochrony, in both the accumulation and the fleetingness of time, is the formation of Little Saigon or the New Saigon and the occasional staging of anti-Communist commemorative parades. These heterotopic spaces are constructed to orchestrate and disperse a regulated collective memory. In Little Saigon, from a Foucauldian perspective, "time never stops building up and topping its own summit" (Foucault, 1986, p. 26). Rather, the daily lives of its refugee residents are informed by anti-Communist activities. 
The exiled communities of the New Saigon in "War Years," for instance, perpetuates a particular revolutionary vision of anti-Communist politics within their community by supporting "a guerrilla army of former South Vietnamese soldiers ... to resurrect the republic of the South" (Nguyen, 2017, p. 51). Besides, within these heterotopic spaces, there are other heterochronies that incorporate "temporal discontinuities" and can be found in occasional "parades and memorials in Little Saigon" (Nguyen, 2017, p. 154). Through these heterotopic experiences, many of the Vietnamese Americans seek to gain visibility and social acceptance by displaying a sign of allegiance to mainstream anti-Communist ideology. In the context of the post-9/11 discourse of the "War on Terror" and the prevailing struggle against orientalist ideologies, following the logic of visibility sounds prudent.

Such temporal spaces of visibility - e.g., parades, memorials, and church gatherings"always presuppose a system of opening and closing that both isolates them and makes them penetrable" (Foucault, 1986, p. 26). Entry to these spaces not only entails performing rituals but also is inextricably bound up with time. An illustrative example is given in "Someone Else Besides You" where, every few months, former Vietnamese anti-Communist army men wear their vintage camouflage uniforms "to march in the honor guard for parades and memorials in Little Saigon" (Nguyen, 2017, p. 154). The rituals are performed as partly political and more as social gestures to gain visibility and recognition by others. This is more obvious when the narrator's father in "War Years" suggests that "paying a little hush money" to support Vietnamese anti-Communist groups in America would make their lives a lot easier (Nguyen, 2017, p. 53). This realization that entry to these heterotopic spaces grants individuals social status leads the exilic characters to appreciate the transient fashionability of such spaces as well as the importance of being seen as a normal, decent and obedient citizens.

\section{FORMATION OF DESIRED KNOWLEDGE: HETEROTOPIA REVISITED}

In Nguyen's stories, the juxtaposition of incompatible spaces - the monstrous Communist North vs. the Republic South - in the portrayed Vietnam, the intrinsic contestation of order, and the unavoidable creation of continual spatio-temporal disruptions, on the one hand explains the contingency of the production of knowledge on spatiality, and on the other, discloses the principles that formulated various forms of knowledge. In The Order of Things, Foucault (1994) explains that knowledge is formed in space, as a product of a battle between ways of knowing. Heterotopic spaces forge new forms of knowledge by suspending, inverting, contesting and contradicting order and space. In other words, heterotopias produce knowledge and power by re-ordering the space upon which knowledge is formed. The re-ordering and problematisation of a space of knowledge, however, involves a certain degree of distancing from the object of knowledge. As Foucault explains, "keeping the object at a distance, differentiating oneself from it and making one's separation from it" allows an understanding of that object and the production of the knowledge possible (Foucault, 2000, p. 11). The Refugees formulates a new space for knowledge. Through native informants, Vietnam is presented as a heterotopic space in relation to itself and to the eutopian space of America. The country serves as a Foucauldian operating table serving polar opposites of the hypotopian Communist North and the hypertopian Republic South as two contesting objects of knowledge. The metaphoric table is both isolated and penetrable, and the ongoing conflict within it, in Foucauldian parlance, produces knowledge. The clash of forces - i.e., of Communist North vs. non-Communist South-leads to the formation of knowledge which the observer, the one who distances himself, seeks to manipulate or give order to. Thus, as a space, Vietnam is both the locus of knowledge formation and the outcome of subjugation of knowledge. 
Therefore, what constitutes Vietnam as a heterotopia in relation to the US is the appropriated discourses around the popular and official historiographies of the country in America. Here, the term, historiography, refers to the selective spatio-temporal ways of remembering that individuals and groups employ to make meaningful sense of present and the past. Hence, an actual 'real' space of the homeland becomes the locus of appropriated memories of spatio-temporal disruptions. The last story of the collection, "Fatherland" offers a perfect example of the ways a non-fictional space becomes a fictional country which encloses different spatio-temporal spaces, or real and un-real spaces of past, present and future. For Phuong and her parents, the here and now Vietnam is a hypotopian space that reflects undesirable conditions of life. In the past, it was a model of de-generate dystopia where systems of repression and exclusion were appropriated, and where non-Communists like Phuong's father found themselves in labour camps, where they "ate roots and manioc to live," where "people caught dysentery or malaria or dengue fever like the common cold and just died," and where they had almost no "blood left for the leeches" (Nguyen, 2017, p. 189). In the present, it is "boring" for Phuong and "not big enough for the desires in her heart" (p. 200). This hypotopian space, nonetheless, is a "relational space" that makes sense only in connection to a fictional or real yet distanced locality. For Phuong, this opposite locality is offered in the United States, where she can realize her individual freedom. What is presented of Vietnam, therefore, is not the actual "real" place itself but the formulated space between Vietnam and America as the other fictional place. Knowledge, according to Foucault, "always occurs in the interstice" (Foucault, 1977, p. 150). In a similar way, meaning and memories in "Fatherland" are constructed spatio-temporally, through heterotopic spaces: from a dystopian past for Phuong's parents, to a hypotopian present in "here and now" Vietnam for Phuong, to a utopian future in America for Phuong and other refugees such as her sister, Vivien.

Such heterotopic interpretation of Vietnam which is imposed on the Vietnamese Americans' shared past is along the established mainstream perspectives that by monopolizing knowledge-producing practices have aimed to subjugate collective memory and impose certain epistemic exclusions. The monopolization occurs by either a systematic elimination of certain historical narratives or a structured falsification and distortion of those accounts. In Society Must Be Defended, Foucault clarifies that subjugated knowledges can refer to two things: either the "historical contents that have been buried or masked in functional coherences or formal systematizations," or the narratives that have been disqualified "as insufficiently elaborated knowledges: naive knowledges, hierarchically inferior knowledges" (Foucault, 2003, p. 7). Nguyen's citation of James Fenton's “A German Requiem” in the opening to The Refugees is perhaps the best reflection of Foucault's notion of subjugated knowledge. According to Fenton, it is not the memories that haunts a person, but "[i]t is what you have forgotten, what you must forget. What you must go on forgetting all your life" (Nguyen, 2017, p. vii). This non-linear form of memory and knowledge, or the fictional heterotopia, is vividly illustrated in other stories: In "The Americans," when the former American pilot, James Carver, is confronted with historical contents - and the ethical question - of his bombing thousands of innocent Vietnamese, he considers those memories as unworthy of epistemic respect, and recalls instead the official demonizing histories of the country as "a land of bad omens and misfortune so severe he wanted nothing more to do with it than fly over it" (p. 144). As an American citizen, the subjugated knowledge about Vietnam is so deeply inscribed in his cognitive, affective, and political life that even now when he ventures into the country, "[a]1l of the sights, sounds, and smells" repel him (p. 137). This demonizing discourse is further reinforced and diffused through individual expressions of Vietnamese war refugees in America whose narratives are formed in alignment with state-regulated memories. For the narrator's father in "Someone Else Besides You," Vietnam is a projection of a dystopian past and a hypotopian present that offers anti-Communists like him nothing but punishment and suffering. Therefore, on certain 
occasions and together with his fellow anti-Communists, he commemorates the war for freedom and democracy by wearing his "vintage camouflage paratrooper's uniform that he'd worn during the war ... to march in the honor guard for parades and memorials in Little Saigon" (p. 154).

Even though participation in the collective ritual performance is to commemorate the war as a heroic struggle of liberation against Communist autocracy, it is semantically infused with diasporic struggles for American identity formation and can likewise be interpreted in relation to hegemonic struggles to advance American nationalism. As the commemoration is in accordance with the established practices of remembering the war in America, the father's active engagement in the parades serves as a signal of his "allegiance to 'America' and being 'American' by the same logic of visibility" that marks him as un-American and a potential Communist agent threatening the American democracy from within (Grewal, 2005, p. 212). The prevailing discourses of American nationalism have forged diasporic subjects who present themselves as "free" in comparison to their "victim" countrymen in the Communist Vietnam. Thus, the power of American nationalism is visible in its ability to "produce provisional national subjects out of immigrants and refugees" (Grewal, 2005, p. 8), who serve as effective agents to (re-)produce and circulate framed narratives.

The particular spatio-temporal modalities of remembering, or knowledge formation, is closely connected to what Soja (1989) explains as "the spatialization of history, the making of history entwined with the social production of space, the structuring of a historical geography" (p. 18). The characterization of a space as dystopian or hypotopian is historically constructed by mainstream capitalist ideology in America; and since the formation of "war on terror" discourse in the aftermath of $9 / 11$ events, the spatialisation has been reinforced in ways that any (potentially) Communist space is considered as the heterotopia of the other. In Nguyen's stories, the very visual solastalgic depiction of Vietnam as a space where Vietnamese characters are portrayed as victimized, isolated, tormented and traumatized not only complies with the established official collective memories in America (Eyerman et al., 2017, p. 13), but also has all the features of Soja's notion of political "reformation of geographical landscapes," by which he refers to emplacements of characters in (re)formulated spatio-temporal contexts in the process of making histories or fabricating desired knowledge(s).

\section{CONCLUSION}

An exploration of spatial mechanisms in Viet Thanh Nguyen's The Refugees revealed that the stories construct an "other space" that affects the formation of a heterotopia fashioned systematically from the (diasporic) Vietnamese' solastalgic, dystopian perceptions of their country of birth both before and in the aftermath of its Communist takeover in 1975. Both re1975 Vietnam's portrayals, constructed of two contradicting geographical imaginations: an undesirable hypotopian North and an agreeable republican South, and the post-1975 Vietnam function as a specific kind of heterotopian experience for the non-Communist Vietnamese, in particular for the refugees in America. The stories demonstrate the ways in which these people become victims of Communism, an ideology that has posed an existential threat to their beloved country as well as a potential rupture to the civil and liberal state of America. Moreover, the analysis of space and time shows that memories of loss, trauma and pain in Nguyen's fiction tell only one side of the story while masking the other side as unworthy of epistemic respect. For instance, narratives of "how anti-Communism was forged through a history of warfare and nation-building" are systematically erased or manipulated from the official historiography in America (Y. T. Nguyen, 2018, p. 87) are examples in which these depictions are completely missing from The Refugees. In particular, the collection's one sided 
accounts do not acknowledge the ways (North) Vietnamese became subjects of antiCommunist "victimizers" - memories that, if appreciated, could destabilize the existing spatial formations.

The subjugation of such memories and the heterotopian presentation of Communist Vietnam displays an inverse mirror for the United States, reflecting the potential deviance of American citizens, and directs the monitoring gaze towards them to spot and control potential irregularities. The reversal of the gaze unravels the ways American citizens are monitored as they are located in a potential "state of deviance" as a consequence of an imminent Communist threat within the contemporary discourse of "the war on terror." More specifically, they mirror the ways Vietnamese Americans are situated in a "state of crisis" as a result of the way they are ontologically objectified. Hence, the exercise of spatial formations in Nguyen's fiction takes a political perspective, positing the discursive and non-discursive aspects of microphysics of power, that aim to realize the dream of a pure community by regulating the political boundaries of place. In other words, the particular arrangement of spaces within or beyond some non-discursive spaces together with the strategic monopolization of knowledgeproducing practices presents insights into the effects of disciplinary power, which is exercised in compliance with the existing "strategic memory projects" and "place- making" in American policies to form anti-Communist "exile identities" (Aguilar-San Juan, 2009, pp. 64-5), with the aim of pre-empting potential terrorist acts. In this manner, Nguyen's collection of short stories fits into a model of controlled mechanism that is in keeping with the power of security functioning within the contemporary discourse of the war on terror in America.

\section{ACKNOWLEDGMENT}

This work was supported by the short-term grant [304/PHUMANITI/6315300] from Universiti Sains Malaysia (USM). The author is also indebted to two anonymous reviewers for their valuable insights on an earlier version of this manuscript.

\section{REFERENCES}

Aguilar-San Juan, K. (2009). Little Saigons: Staying Vietnamese in America. Minneapolis: University of Minnesota Press.

Albrecht, G. (2006). Solastalgia. Alternatives Journal, 32(4/5), 34-36.

Amarinthnukrowh, P. (2019). "So, Obama is a Muslim?": Toward figurative spaces and blends in US same-sex marriage discourse. 3L: Language, Linguistics, Literature ${ }^{\circledR}, 25(4), 1-15$. doi: 10.17576/3L-2019-250401

Appy, C. G. (2015). American reckoning: The Vietnam war and our national identity. New York: Penguin.

Ashcroft, B. (2009). The ambiguous necessity of utopia: Post-colonial literatures and the persistence of hope. Social Alternatives, 28(3), 8-14.

Ashcroft, B. (2017). Visions of the not-yet: Literature and postcolonial utopia. SARE: Southeast Asian Review of English, 52(1), 1-24.

Asl, M. P. (2018). Practices of counter-conduct as a mode of resistance in Middle East women's life writings. $3 L$ : Language, Linguistics, Literature ${ }^{\circledR}, 24(2)$, 195-205. doi:10.17576/3L-2018-2402-15

Asl, M. P. (2018). Fabrication of a desired truth: the oblivion of a Naxalite woman in Jhumpa Lahiri's The Lowland. Asian Ethnicity, 19(3), 383-401. doi:10.1080/14631369.2018.1429892

Asl, M. P. (2019). Leisure as a space of political practice in Middle East women life writings. GEMA Online ${ }^{\circledR}$ Journal of Language Studies, 19(3), 43-56. doi:10.17576/gema-2019-1903-03

Asl, M. P., \& Abdullah, N. F. L. (2017). Practices of (Neoliberal) Governmentality: Racial and Gendered Gaze in Jhumpa Lahiri's Fiction. 3L: Language, Linguistics, Literature, 23(2), 123-140. doi:10.17576/3L-20172302-10

Asl, M. P., Abdullah, N. F. L., \& Yaapar, M. S. (2020). Panoptic spaces and the framings of South Asian diaspora in Jhumpa Lahiri's selected short stories. Cogent Arts \& Humanities, 7(1). doi: 10.1080/23311983.2020.1728022

Billingham, P. (2000). Sensing the city through television: Urban identities in fictional drama. Bristol: Intellect.

Booker, M. K. (1994). The dystopian impulse in modern literature: Fiction as social criticism. Westport, CT: Greenwood Press. 
Doudaki, V. (2018). Heterotopias of identity in Sex and the City. Polis(17), 5-22.

Dwyarie, R. D., \& Tjahjani, J. (2019). Intercultural concepts in place cliché by Jacques Godbout. 3L: Language, Linguistics, Literature ${ }^{\circledR}, 25(3), 137-149$. doi: 10.17576/3L-2019-2503-11

Eyerman, R., Madigan, T., \& Ring, M. (2017). Cultural trauma, collective memory and the Vietnam War. Politička Misao, 54(1-2), 11-31.

Foucault, M. (1977). Nietzsche, genealogy, history. In D. F. Bouchard (Ed.), Language, counter-memory, practice: Selected essays and interviews (pp. 139-164). Ithaca: Cornell University Press.

Foucault, M. (1986). Of other spaces. diacritics, 16(1), 22-27. doi:10.2307/464648

Foucault, M. (1994). The order of things: An archaeology of the human sciences. Vintage Books.

Foucault, M. (1995). Discipline and punish (A. Sheridan, Trans.). New York: Vintage.

Foucault, M. (1998). Different spaces (R. Hurley, Trans.). In James D. Faubion (Ed.), Aesthetics, method, and epistemology (Vol. 2, pp. 175-185). London: Allen Lane.

Foucault, M. (1999). Space, power and knowledge. In S. During (Ed.), The cultural studies reader (2 ed., pp. 134141). London: Routledge.

Foucault, M. (2000). Truth and juridical forms (R. Hurley, Trans.). In J. D. Faubion (Ed.), Essential works of Michel Foucault (Vol. 3, pp. 1-89). London: Penguin.

Foucault, M. (2003). Society must be defended: Lectures at the Collège de France, 1975-1976 (D. Macey, Trans. M. Bertani, A. Fontana, \& F. Ewald Eds.). New York: Picador.

Grewal, I. (2003). Transnational America: Race, gender and citizenship after 9/11. Social Identities, 9(4), 535561.

Grewal, I. (2005). Transnational America: Feminisms, diasporas, neoliberalisms. London and Durham: Duke University Press.

Hook, D., \& Vrdoljak, M. (2002). Gated communities, heterotopia and a "rights" of privilege: aheterotopology'of the South African security-park. Geoforum, 33(2), 195-219. doi:10.1016/S0016-7185(01)00039-2

Howarth, D. (2006). Space, subjectivity, and politics. Alternatives, 31(2), 105-134. doi:10.1177/030437540603100201

Janette, M. (July 2018). Vietnamese American Literature. In P. Rabinowitz (Ed.), Oxford Research Encyclopedia of Literature: Oxford University Press. Retrieved 26 Dec. 2019 . doi: 10.1093/acrefore/9780190201098.013.895

Johnson, P. (2006). Unravelling Foucault's 'different spaces'. History of the Human Sciences, 19(4), 75-90. doi:10.1177/0952695106069669

Klein, C. (2003). Cold war Orientalism: Asia in the middlebrow imagination, 1945-1961. Berkeley, Los Angeles, and London: University of California Press.

Le Espiritu, Y. (2006). The "We-Win-Even-When-We-Lose" Syndrome: US Press Coverage of the Twenty-Fifth Anniversary of the" Fall of Saigon". American Quarterly, 58(2), 329-352.

Leib, R. S. (2017). Spaces of the self: Foucault and Goffman on the micro-physics of discipline. Philosophy Today(March 2017), 189-210. doi:10.5840/philtoday2017321153

Levitas, R. (2003). Introduction: The elusive idea of utopia. History of the Human Sciences, 16(1), 1-10. doi:10.1177/0952695103016001002

Nguyen, V. T. (2015). The Sympathizer. New York: Grove Press.

Nguyen, V. T. (2016). Nothing ever dies: Vietnam and the memory of war. Cambridge, MA: Harvard University Press.

Nguyen, V. T. (2017). The Refugees. London, UK: Crosair.

Nguyen, Y. T. (2018). (Re) making the South Vietnamese past in America. Journal of Asian American Studies, 21(1), 65-103. doi:10.1353/jaas.2018.0003

Pelaud, I. T. (2011). This is all I choose to tell: History and hybridity in Vietnamese American literature. Philadelphia, Pennsylvania: Temple University Press.

Pinak, M. Z. A., \& Lalbakhsh, P. (2019). Orientalism on the Margins: Inter-Subjective Space in Edward Granville Browne's A Year amongst the Persians. 3L: Language, Linguistics, Literature ${ }^{\circledR}, 25(3), 33-45$. doi: 10.17576/3L-2019-2503-03

Public Law 107-56. (2001). America Retrieved from https://www.govinfo.gov/content/pkg/PLAW107publ56/pdf/PLAW-107publ56.pdf.

Radzilowski, J. (2009). Introduction: Ethnic anti-Communism in the United States. In I. Zake (Ed.), Anticommunist minorities in the US: Political activism of ethnic refugees. New York: Palgrave Macmillan.

Schlund-Vials, C. J., Võ, L. T., \& Wong, K. S. (2015). Keywords for Asian American studies. New York: New York University Press.

Sheth, F. A. (2011). The war on terror and ontopolitics: Concerns with Foucault's account of race, power sovereignty. Foucault Studies, 12, 51-76. doi:10.22439/fs.v0i12.3337

Silverman, H. J. (1980). From utopia/dystopia to heterotopia: An interpretive topology. Philosophy \& Social Criticism, 7(2), 170-182. doi:10.1177/019145378000700203 
Soja, E. W. (1989). Postmodern geographies: The reassertion of space in critical social theory. London: Verso. Sylvester, C. (2017). Curating and re-curating the American war in Vietnam. Security Dialogue, 49(3), 151-164. doi:10.1177/0967010617733851

Topinka, R. J. (2010). Foucault, Borges, heterotopia: Producing knowledge in other spaces. Foucault Studies(9), 54-70. doi:10.22439/fs.v0i9.3059

Villet, C. (2018). South Africa as postcolonial heterotopia: The racialized experience of place and space. Foucault Studies(24), 12-33. doi:10.22439/fs.v0i24.5523

Vu, N. A. (2015). From victimization to transnationalism: A study of Vietnamese diaspora intellectuals in North America. (PhD), McMaster University, Ontario. Retrieved from http://hdl.handle.net/11375/18387

Whittaker, T. (2011). Between the dirty and the pretty: Bodies in utopia in Dirty Pretty Things. International Journal of Cultural Studies, 14(2), 121-132. doi:10.1177/1367877910382187 